\title{
Initial Evaluation on Microwave Incinerated Rice Husk Ash (MIRHA) Foamed Concrete Using Neural Network
}

\author{
Ridho Bayuaji \\ Program Studi Diploma Teknik Sipil FTSP ITS, Surabaya \\ Email: bayuaji@ce.its.ac.id
}

\begin{abstract}
The purpose of this study was to determine whether foamed concrete could achieve a strength requirement for structural application, while retaining its characteristics of low density, flowing workability and self-compacting. This investigation was focused on both designing compositions foamed concrete with pozzolanic material affect that has strength and density according to ASTM $C$ 330. Neural network modelling, as observed, could enable the application of the mix proportion of foamed concrete to reach the compressive strength more than 17 MPa in which density was at $1400 \mathrm{~kg} / \mathrm{m}^{3}$ with $\mathrm{s} / \mathrm{c}$ of $0,5.1600 \mathrm{~kg} / \mathrm{m}^{3}$ with $\mathrm{s} / \mathrm{c} 0,75$ and $1800 \mathrm{~kg} / \mathrm{m}^{3} \mathrm{~s} / \mathrm{c}=1$. The neural networks model could be used as an alternative model in developing the tools to predicting the foamed concrete strength
\end{abstract}

Keywords: Rice husk ash, foamed concrete, neural network, compressive strength.

Abstrak

Penelitian ini mempunyai tujuan untuk menentukan beton porus dapat mencapai persyaratan kekuatan untuk aplikasi struktural, selain itu tetap mempertahankan karakteristik densiti rendah, kemampuan mengalir, dan tanpa pemadatan. Penelitian ini difokuskan pada rancangan komposisi beton porous dengan pengaruh bahan pozzolan dengan memiliki kekuatan dan densiti yang memenuhi ASTM C 330. Model Neural Network digunakan untuk aplikasi menentukan komposisi campuran untuk mencapai kuat tekan lebih dari 17 MPa dengan densiti: $1400 \mathrm{~kg} / \mathrm{m}^{3}$ dengan pasir $/ \mathrm{semen}=0,50,1600 \mathrm{~kg} / \mathrm{m}^{3}$ dengan pasir $/ \mathrm{semen}=0,75 \mathrm{dan} 1800$ dengan pasir/semen $=1$. Neural network dapat digunakan sebagai alat bantu alternative untuk memprediksi kuat tekan beton porus

Kata kunci: Abu sekam padi, beton porus, neural network, kuat tekan

\section{Introduction}

A greater interest has nowadays been focused on the production of lightweight construction materials to replace conventional concrete. Compared to a structural weight ordinarily about 150 pounds per cubic foot $\left(2400 \mathrm{~kg} / \mathrm{m}^{3}\right)$, concrete produced with such materials is broadly classified as structural lightweight concrete usually in the range of 90-120 pounds per cubic foot (1440$1920 \mathrm{~kg} / \mathrm{m}^{3}$ ) in weight The structural lightweight concrete is primarily used to reduce the dead load of a concrete structure. This can allow a structural designer to reduce the size of columns, footings and other load bearing elements. Other mechanical and durability performance requirements are similarly proper and it can be planned to achieve similar strengths as normal weight concrete. It has been found that the weight of the concrete can be considerably reduced by substituting lightweight aggregates and by introducing stable voids. The voids can be produced by gas or air commonly by means of a

Jurnal APLIKASI: Media Informasi \& Komunikasi Aplikasi Teknik Sipil Terkini Halaman 39 
foaming agent; thus making it to be called as foamed concrete. The air bubbles can be produced from formed foam (made in special foam generator) introduced into the mixer together with cement, water and sand, or alternatively through the mix of foam concentrate and the other ingredients into a high shear mixer.

Foamed concrete, which is sometimes referred to cellular concrete, is a versatile material that consists principally of cement-based mortar or paste (base mix) mixed with at least $20 \%$ by volume air. Typically, it has high porosity and low strength, which has resulted in the limited use of pervious concrete. Improving the strength and durability of pervious concrete will allow an increase in its use in these regions. The criteria of structure of lightweight concrete per ASTM C 330 requires minimum 28-day cylinder compressive strength of $17.5 \mathrm{MPa}$ and maximum dry density of $1850 \mathrm{~kg} / \mathrm{m}^{3}$.

A variety of evidences to enhance the compressive strength and high performance (PAN Zhihua, 2007) of foamed concrete to change the fine aggregate with high fly ash (Pan Zhihua 2007, Jones 2005) by means of silica fume and ultra-fine silica powder, and fly ash without any use of sand to decrease w/c, high performance foamed concrete is addressed to the characteristics of lightweight, high strength and low thermal conductivity. The research conducted by Hamidah et al. shows that the lower ratio of sand-cement has resulted in foamed concrete of higher compressive strength of foamed concrete that the mix proportion of mix needs a huge amount of cement. It then indicates that cementitious material is interesting to be more explored.

The study of hydration process of cementitious material is very important to achieve the mechanical properties and durability as required. It has been commonly known that the development of cementitious strength is by increasing hydration time. It is observed that this strength increase is due to the increase of hydration products' number as the time progress.

These entire factors must be well concerned in estimating strength of hydration degree or parameter related to it. In earlier work, it has been suggested that cement strength is related to the existing gel/space ratio, which in turn depends again on the amount of formed hydrates. The gel/space ratio $\mathrm{X}$ was defined as follows:

$\mathrm{x}=\frac{\text { gel volume }}{\text { gel volume }+ \text { volume of capillary }}$

The following equation is suggested to express the relationship between the cement strength and the gel/space ratio:

$\alpha=a_{0} X^{n}$

where $\alpha_{0}$ denotes strength at zero capillary porosity and $\mathrm{n}$ denotes constant depending on the type of cement.

The increase of strength with the increasing degree of hydration appears due to two following separate factors: 
(a) To an increase of the amount of hydrate in the system at the expense of non-hydrated material and water, and

(b) To a simultaneous decrease of the overall porosity in view of progressive hydration.

The use of replacement materials in Portland cement has recently been gaining much attention. The world situation regarding the cement demand and the energy cost has led to the mix of some materials such as ground granulated blast furnace slag (GGBFS) and pulverized fuel ash (PFA) in use. In blended cements, the replacement materials may take part in the hydration reactions and contribute to the hydration products.

Two groups of commonly recognized cement replacements are pozzolanas and latently hydraulic materials. The first group reacts with the $\mathrm{CH}$ produced during the cement hydration, while the second one is hydraulic.

Meanwhile, in Malaysia, a large amount of rice husks is annually produced almost reaching 2.2 million tons and in world, the total annual production is about 600 million tons as a waste product from the rice industry after rice husk was burnt. Here, about $20 \%$ of the rice husk will become Rice Husk Ash (abbreviated as RHA) (PAN Zhihua1). This means that in Malaysia 0.44 million tons of RHA are produced per annum. RHA contains a high amount of $\mathrm{SiO}_{2}$, most of which is in amorphous form which makes it RHA (Zhihua1, Jones 2005) to be a pozzolanic material.
Pozzolana as defined by ASTM (C 618 1997d) is a siliceous or siliceous and aluminous material in its composition. In general, pozzolana has little or even no cementing property but when it is in high fineness and in the presence of moisture, it can react with $\mathrm{Ca}(\mathrm{OH})_{2}$ at room temperature to provide cementing property to ASTM (C $618 \sim 1997 d)$. By a proper control of the incineration process (Kearsley EP. 2001), the quality of RHA can be assured. RHA has been used as a highly reactive pozzolanic material purposely to improve the microstructure of the interfacial transition zone (ITZ) between the cement paste and the aggregate in high-performance concrete.

The effect of rice husk ash content as the partial replacement of cement on compressive strength and volume changes of different mixes was investigated. Test results then showed that up to $40 \%$ replacement could be made without any significant change in compressive strength compared with the control mix (Jones 2005).

The utilization of rice husk ash as a pozzolanic material in cement and concrete can provide several advantages, such as to improve strength and durability properties, reduce materials cost in view of cement savings and environmental benefits related to the disposal of waste materials and reduce carbon dioxide emissions.

In turn, the main aim of this research is to determine the composition of material proportion of foamed concrete for 
structural lightweight concrete according to ASTM C 330.

\section{Methodology}

Neural network modelling (Moyad,1984), as observed, could enable the application of the mix proportion of foamed concrete to reach the compressive strength more than $17 \mathrm{Mpa}$ in which density was at $1400 \mathrm{~kg} / \mathrm{m}^{3}$ with $\mathrm{s} / \mathrm{c}$ of $0,5.1600 \mathrm{~kg} / \mathrm{m}^{3}$ with $\mathrm{s} / \mathrm{c} 0,75$ and $1800 \mathrm{~kg} / \mathrm{m}^{3} \mathrm{~s} / \mathrm{c}=1$. On the other hand, the relation between logarithm of strength and water cement ratio has decreased w/c less than 0,5 (Van 1991). Figure 1 shows the proposed model based on neural network. It consisted of particle size distribution of sand, sandcement ratio input, density input, and compressive strength as output.

The constituent materials have been used in a laboratory to produce foamed concrete constituting (i) Portland cement (Ordinary Portland Cement BSEN 197-1), (ii) natural sand, with 60-95\% passing $1.18 \mathrm{~mm}$ sieve, (iii) MIRHA with high reactive silica content, controlled combustion of rice husk, (iv) free water to give a water/cement ratio (w/c) of 0.40 and 0.3 and (v) superplasticizer to give 1-2\%. The surfactant used for the preformed foam production was conducted by aerating palm oil based LCM in a ratio of 1:30 (by volume), and density of $70-80 \mathrm{~kg} / \mathrm{m}^{3}$. table 1 provides the summary of mix proportions of the 1400, 1600 and 1800 $\mathrm{kg} / \mathrm{m}^{3}$ plastic density foamed concretes that were calculated by equating the design plastic density value to the sum of solids (cement and fine aggregate) and water in the mix. The chemical properties of MIRHA and OPC "Tasek" are shown in table 2 .

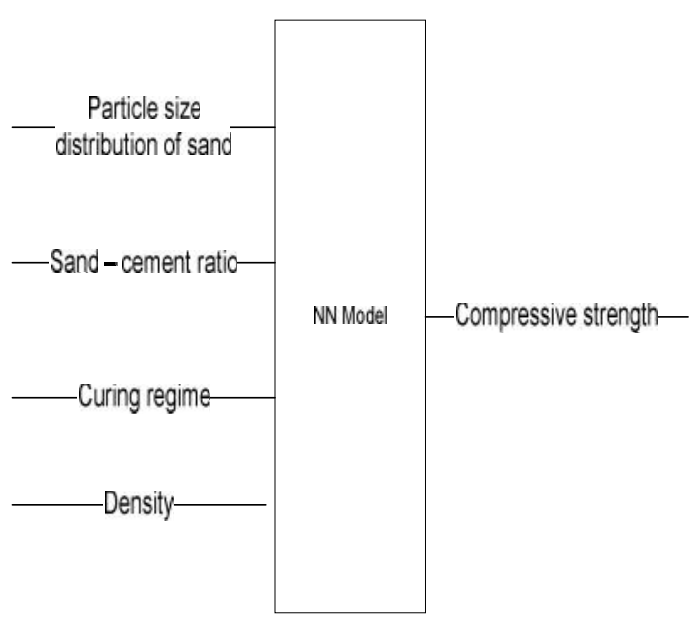

Figure 1. Proposed model based on NN for Compressive Strength from the data of Hamidah et al.

The density of foamed concrete is dependent upon the foam volume and in the next step it acts as a vital parameter affecting strength, porosity, and permeability and hydration process. Hence, there is a need of tool to control the density. A statistic process control has been used to control the density and it can be accepted and continued to the next step.

\section{Result and Discussion}

Figure 2 presents the graph of predicted compressive strength in contrast to experimental compressive strength values. As shown in the figure, the correlation coefficient at 0.9496 is evenly distributed on both sides of the line, indicating an extremely good performance of the model. 
Table 1. Mixture proportion of foamed concrete

\begin{tabular}{ccccccc}
\hline No. & Water/binder & $\begin{array}{c}\text { Plactic } \\
\text { density }\end{array}$ & $\begin{array}{c}\text { Cement } \\
\mathrm{kg} / \mathrm{m}^{3}\end{array}$ & $\begin{array}{c}\text { Sand } \\
\mathrm{kg} / \mathrm{m}^{3}\end{array}$ & $\begin{array}{c}\text { Water } \\
\mathrm{kg} / \mathrm{m}^{3}\end{array}$ & $\begin{array}{c}\text { Foam } \\
\text { liter }\end{array}$ \\
\hline 1 & 0.3 & 1400 & 780.00 & 393.72 & 217.65 & 386.16 \\
\hline 2 & 0.3 & 1600 & 790.00 & 584.46 & 218.69 & 309.97 \\
\hline 3 & 0.3 & 1800 & 790.00 & 788.46 & 216.44 & 235.24 \\
\hline 4 & 0.4 & 1400 & 750.00 & 371.28 & 281.04 & 340.76 \\
\hline 5 & 0.4 & 1600 & 780.00 & 561.00 & 283.11 & 257.57 \\
\hline 6 & 0.4 & 1800 & 750.00 & 765.00 & 280.86 & 192.37 \\
\hline & & & means & that the mix proportion of
\end{tabular}

Table 2. Binder Properties

\begin{tabular}{lll}
\hline $\begin{array}{l}\text { Oxide } \\
\text { composition }\end{array}$ & $\begin{array}{l}\text { Weight } \% \\
\text { MIRHA }\end{array}$ & OPC "Tasek" \\
\hline $\mathrm{Na} 2 \mathrm{O}$ & 0,02 & 0,02 \\
\hline $\mathrm{MgO}$ & 0,63 & 1,43 \\
\hline $\mathrm{A} 2 \mathrm{O} 3$ & 0,75 & 2,84 \\
\hline $\mathrm{SiO} 2$ & 90,75 & 20,44 \\
\hline $\mathrm{P} 2 \mathrm{O} 5$ & 2,50 & 0,10 \\
\hline $\mathrm{K} 2 \mathrm{O}$ & 3,77 & 0,26 \\
\hline $\mathrm{CaO}$ & 0,87 & 67,73 \\
\hline $\mathrm{TiO} 2$ & 0,02 & 0,17 \\
\hline $\mathrm{Fe} 2 \mathrm{O} 3$ & 0,28 & 4,64 \\
\hline $\mathrm{SO} 3$ & 0,33 & 2,20 \\
\hline $\mathrm{MnO}$ & 0,08 & 0,16 \\
\hline
\end{tabular}

In figure 3, 4 and 5, statistic process control depicts that all of the densities commonly have a fine variance in the range of 2 standard deviations. It then foamed concrete is suitable for the next procedure

Meanwhile, the compressive strength of foamed concrete as shown in figure 6 and figure 7 are found higher than 17,5 Mpa within 7 days that the requirement the structural application.

Figure 6 shows the relationship between dry density and porosity in which porosity is largely dependent upon dry density. The lowest porosity at $32,3 \%$ was measured for the foamed concrete with a water/cement ratio of 0,4 within 7 days. The permeability of foamed concrete is plotted as function dry density in figure 6 and figure 7.

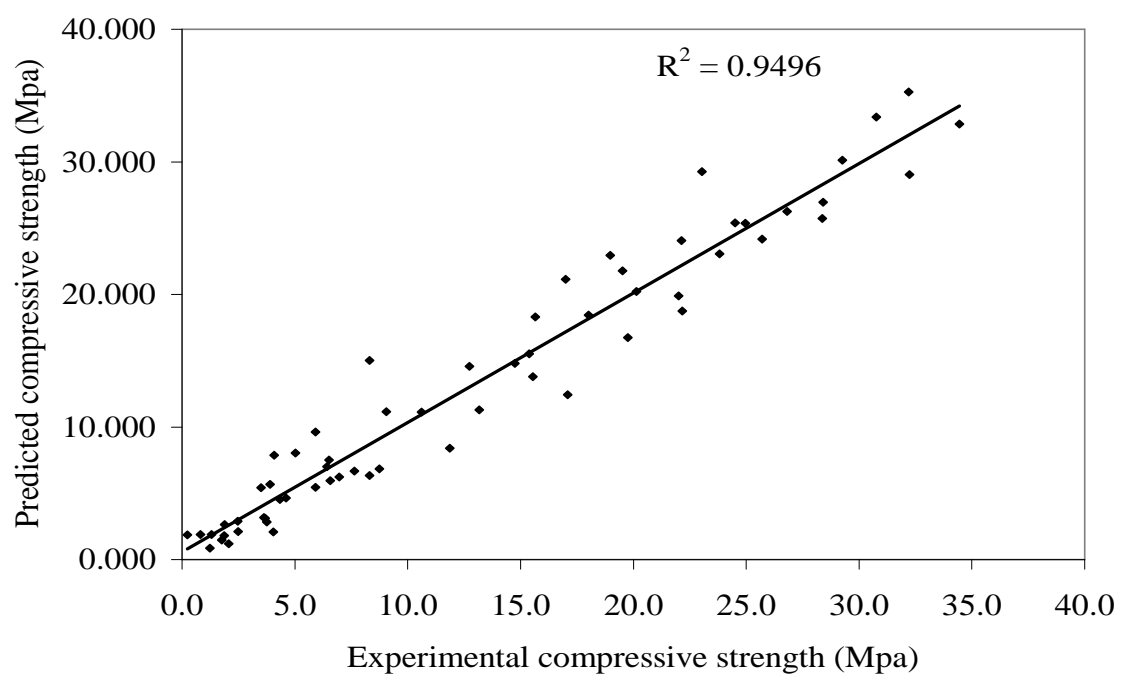

Figure 2. Predicting accuracy of neural-network system 
DATA-SIMCA4.M1 (PCA-X) Shewhart (Subgroup 1): $X \operatorname{Var}\left(\operatorname{Var}_{-}\right.$)

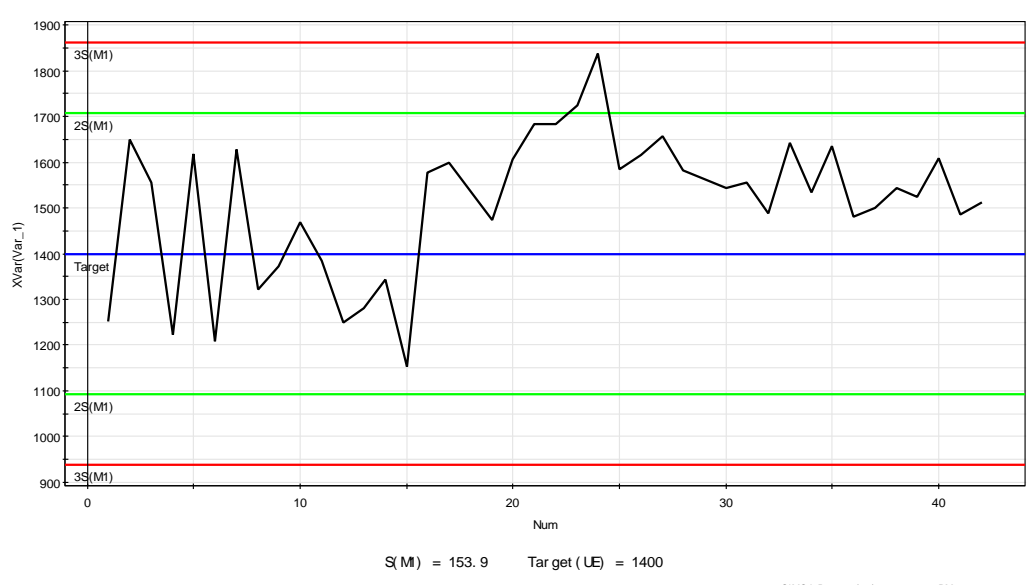

Figure 3. Statistic process control for density $1400 \mathrm{~kg} / \mathrm{m}^{3}$

DATA-SIMCA 1600.M1 (PCA-X)

Shewhart (Subgroup 1): XVar(Var_1)

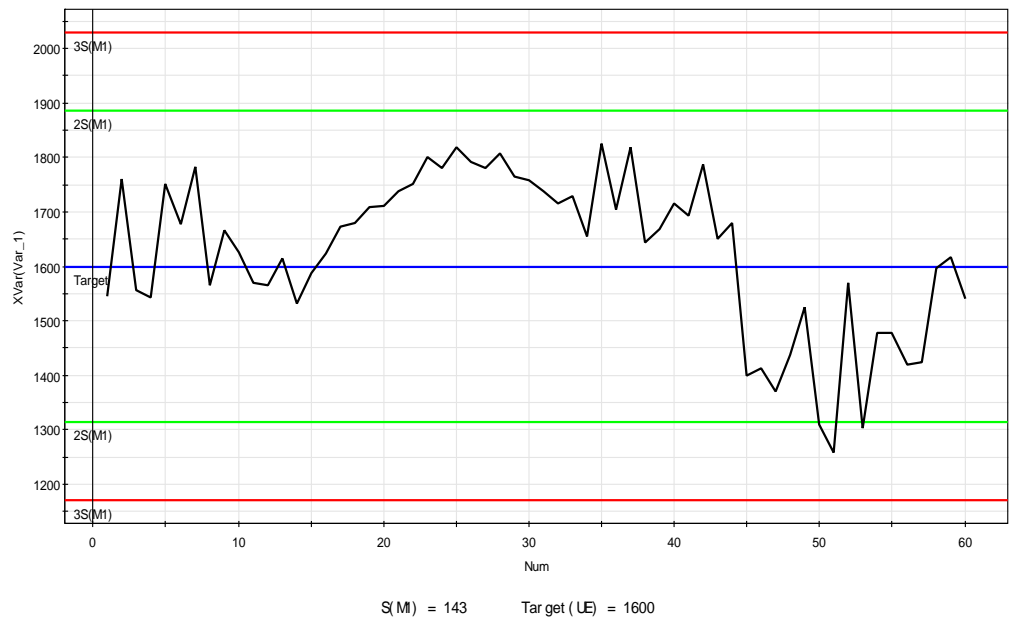

SIMCA.P 11 - 5/15/2008 4:59:38 PM

Figure 4. Statistic process control for density $1600 \mathrm{~kg} / \mathrm{m}^{3}$

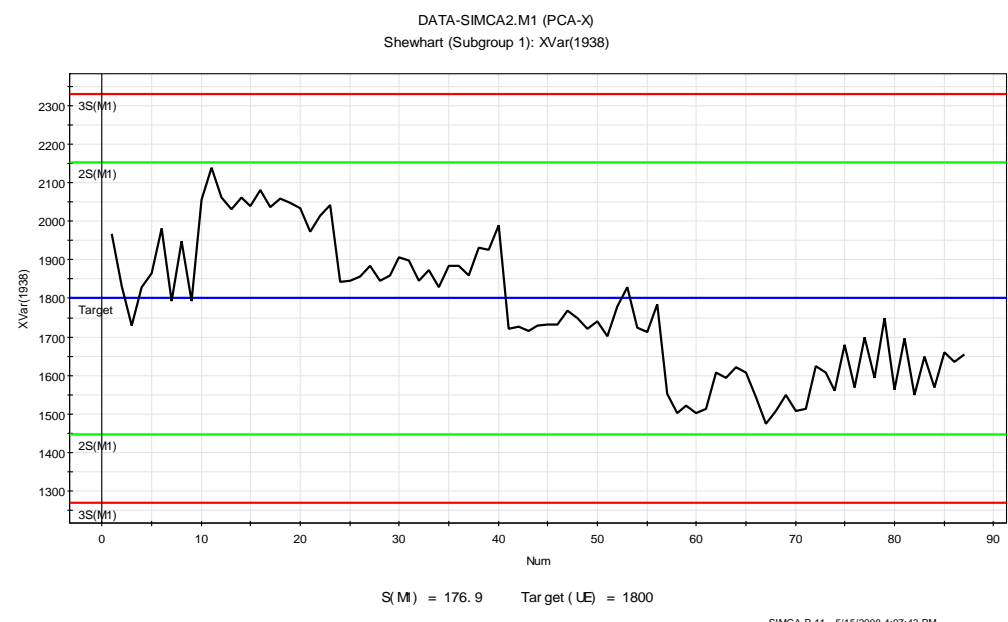

Figure 5. Statistic process control for density $1800 \mathrm{~kg} / \mathrm{m}^{3}$ 


\section{ISSN.1907-753X}

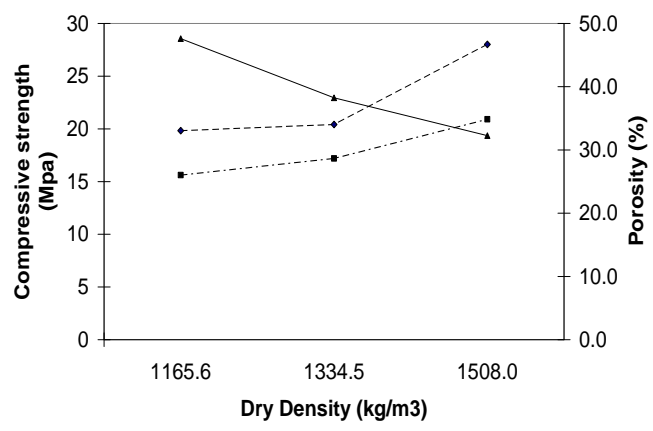

- compressive strength (3 day) - - compressive strength (7 day) - porosity (7 day)

Figure 6. The previous experimental result of Compressive strength and porosity with $\mathrm{w} / \mathrm{c}=0.4$

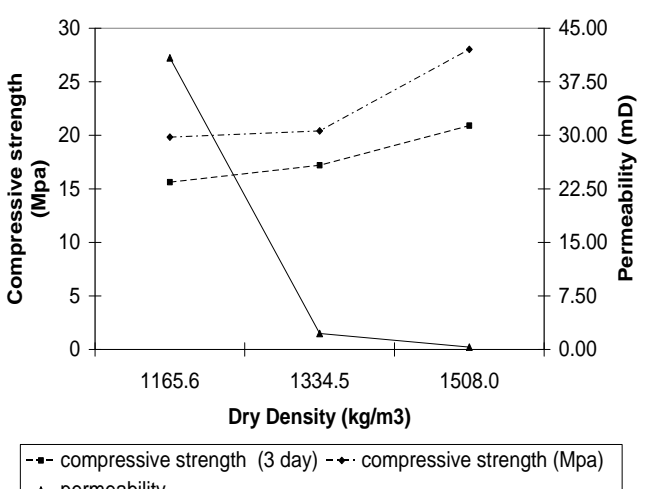

Figure 7. The previous experimental result of Compressive strength and permeability with $w / c=0.4$

On the other hand, the micrograph of the pore boundary of foamed concrete as shown in Figure 8 closely resembles the model of the transition zone in normal concrete.

\section{Conclusions}

The neural networks model was able to well produce modeling with $\mathrm{RMSE}=$ $1.23 \times 10-5$ for water curing in training phase. In validation phase, RMSE is 2.31 x10-5 for water curing. Therefore, the neural networks model could be used as an alternative model in developping the tools to predicting the foamed concrete strength.
Statistic process control shows the density has fine variances. The compressive strength of foamed concrete within 7 days was above the ASTM C330. Porosity and permeability were largely dependent upon dry density. As shown, the micrograph closely resembles the model of the transition zone in normal concrete.

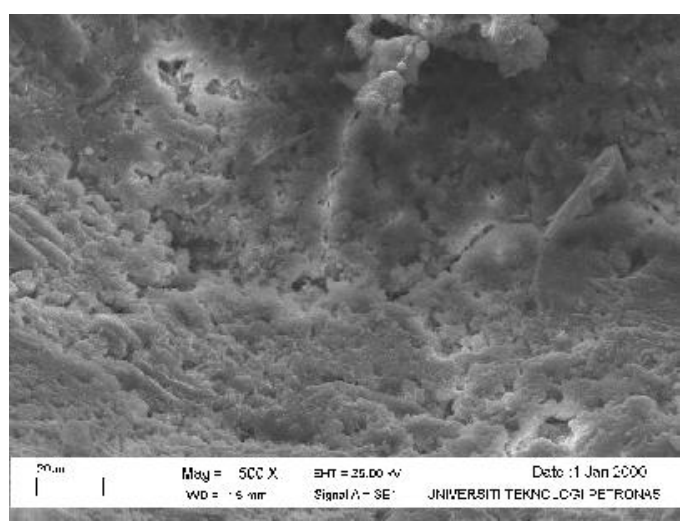

Figure 8. Micrograph of foamed concrete with density $1800 \mathrm{~kg} / \mathrm{m}^{3}, \mathrm{~s} / \mathrm{c}=1, \mathrm{w} / \mathrm{c}=0.3$, 7 day

\section{References}

A.M. Neville. (1995). Properties of Concrete, 4th ed., Longman Essex. England.

Bayuaji Ridho and Fadhil M N., (2008). Prediction of Compressive Strength for Foamed Concrete Using Neural Network. National Postgraduate Conference. Malaysia: UTP.

Kearsley EP, \& PJ Wainwright. (2001).

The Effect of high fly ash content on the compressive strength of foamed concrete, CemConcr Res 31, 105-112.

Kusbiantoro Andre. (2007). The Effect of Microwave Incinerated Rice Husk Ash (MIRHA) On Concrete Properties. Master Thesis. Malaysia: Universiti Teknologi Petronas. 
Mehta, P. K., (1992). Rice Husk Ash-A Unique Supplementary Cement Material. Advances in Concrete Technology, Ed. By Malhotra, CANMET. Ottawa, Canada.

Moyad, Al. Khalaf and Hana A. Yousif. (1984). Use of rice husk ash in concrete, Int J Cement Compos Light Weight Concrete 6, pp. 241248.

M.R. Jones and McCarthy. (2005). Preliminary views on the potential of foamed concrete as a structural material, Magazines of Concrete Research, 57, No1, February, 2131.

MS Hamidah, I Azmi, MR A Ruslan, K Kartini, NM Fadhil. (2005). Optimisatiom of Foamed Concrete Mix of Different Sand-Cement ratio and Curing Conditions, Proceeding from the int. Conference 'Global Construction: Ultimate concrete opportunities', Dundee, 5-7 July 2005, Thomas Telford.

PAN Zhihua1, Fujiwara Hiromi, Wee Tionghuan. Preparation of High Performance Foamed Concrete from Cement, Sand and Mineral Admixtures. DOI 10.1007/s11595005-2295-4.

Paul Klieger and Joseph F. Lamond. Significance of Tests and Properties of concrete and concrte-making materials. ASTM STP 169C.

Van Breugel, K., (1991). Simulation of hydration and formation of structure in hardening cement-based materials. Ph.D thesis submitted to Deflt technological Institute, Netherlands. 